\title{
Characterization of Enterococcal Community Isolated from an Artisan Istrian Raw Milk Cheese: Biotechnological and Safety Aspects
}

\author{
Mirna Mrkonjic Fuka ${ }^{1 *}$, Ana Zgomba Maksimovic ${ }^{1}$, Irina Tanuwidjaja ${ }^{1}$, Natasa Hulak ${ }^{1}$ \\ and Michael Schloter ${ }^{2}$ \\ ${ }^{1}$ Department of Microbiology, Faculty of Agriculture, University of Zagreb, Svetošimunska 25, \\ HR-10000 Zagreb, Croatia \\ ${ }^{2}$ Research Unit for Environmental Genomics, Helmholtz Zentrum München, Ingolstaedter Landstrasse 1, \\ DE-85758 Neuherberg, Germany \\ Received: December 19, 2016 \\ Accepted: June 2, 2017
}

\begin{abstract}
Summary
In this study, prevalence, biotechnological and safety profiles of 588 Enterococcus isolates isolated from raw milk and Istrian cheese during different stages of ripening were analyzed. Despite the low and variable presence of enterococci in milk ((3.65 \pm 2.93$) \log$ $\mathrm{CFU} / \mathrm{mL})$, highly comparable enterococcal populations were established after 30 days of cheese ripening ((7.96 \pm 0.80$) \log \mathrm{CFU} / \mathrm{g})$, confirming Enterococcus spp. as a major part of the core microbiota of Istrian cheese. The dominant species were E. faecium (53.8\%) and E. faecalis $(42.4 \%)$, while minor groups, consisting of E. durans $(2.84 \%)$ and E. casseliflavus $(0.95$ $\%)$, also occurred. A pronounced intraspecies variability was noticed based on molecular fingerprinting, with 35 strains (genotypes) detected. Most of the genotypes were farm-specific with one third being shared between the farms. This genotype variability reflected particular differences of Istrian cheese production, mainly variable salt concentration, ripening temperature and air humidity as well as microclimatic or vegetation conditions. There was considerable variation between the strains of the same species regarding wide range of biotechnologically important traits as well as their ability to survive in simulated gastrointestinal conditions. A considerable number of strains were resistant to critically important antibiotics such as tetracycline (43.56 \%), erythromycin (35.79\%) and vancomycin $(23.48 \%)$. Polymerase chain reaction-based detection did not identify any of the common genetic determinants for vancomycin and erythromycin resistance; for tetracycline tet $M$ gene was detected. The presence of virulence genes including agg, efaAfs, gelE, cylM, cylB, $c y l A$, esp, efaAfm, cob and cpd was frequently recorded, especially among E. faecalis strains.
\end{abstract}

Key words: cheese, spontaneous fermentation, Enterococcus spp., molecular fingerprinting, antibiotic resistance, virulence genes

\section{Introduction}

Enterococci are one of the most common groups of bacteria in diverse ecosystems, mainly due to their high adaptability and resistance to adverse environmental conditions. They have been frequently isolated from natural sources such as soil, water, plants and gastrointestinal

\footnotetext{
*Corresponding author: Phone: +385 (0)1 239 4034; Fax: +385 1239 3881; E-mail: mfuka@agr.hr ORCID IDs: 0000-0002-8494-8805 (Mrkonjic Fuka), 0000-0003-2070-8562 (Zgomba Maksimovic), 0000-0003-1364-2953 (Tanuwidjaja), 0000-0001-8440-128X (Hulak), 0000-0003-1671-1125 (Schloter)
} 
(GI) tract of mammals (1). Also, they are an integral part of many spontaneously fermented, traditional cheese varieties in which they contribute to the fermentation and ripening process $(2,3)$. Thanks to their proteolytic activity, hydrolysis of milk fat by esterase and production of typical flavour components such as acetaldehyde, acetoin and diacetyl $(2,4)$, they are responsible for the development of particular sensory characteristics of many cheese varieties. As indigenous members of the GI tract, enterococci can have beneficial effect on human health by balancing gut microbiota; therefore, they may also act as probiotic bacteria (1).

Enterococcus spp. are nowadays recognized for their beneficial effects on the development of cheese flavour and are considered as an integral part of the natural microbiota of many traditional types of cheese; however, some strains may present an emerging threat due to the enterococcal virulence determinants that are able to cause infections in humans $(3,5)$. Over the last three decades, epidemiological data have noted the emergence of particular ecotypes of enterococci as leading nosocomial pathogens and they have arisen to become a major cause of human diseases, especially in immunocompromised patients (6). Their plasmid and transposon-mediated resistance to tetracycline, erythromycin, chloramphenicol and glycopeptides is considered particularly problematic, since it leads to the increased number of infections related to the acquired antimicrobial resistance of enterococci (6). Their capacity to exchange genetic material by conjugation is well documented (7) and it can take place in GI tract, where genes coding for resistance to antibiotics and virulence factors can be transferred (5). As enterococci are usually present at fairly high levels in ready-to-eat cheese products $(8,9)$, they may have significant influence on consumers' health and as such, their safety aspect should be carefully evaluated.

Istrian cheese is a hard type of artisan raw milk cheese that is manufactured at home, on small scale, on the whole Istrian peninsula, without the addition of starter cultures (10). It is characterized by ripening of 90-120 days. However, because of its popularity in the region and due to the commercial pressure, the ripening time has been shortened and it has become market practice to sell the cheese as soon as possible. During the ripening of Istrian cheese, the number of enterococci reached up to $10^{8}$ per $g$ when assessed by real-time PCR (11). They are also found to be one of the dominant bacterial populations during ripening when denaturing gradient gel electrophoresis (DGGE) or next-generation sequencing approach were applied $(11,12)$. Although total microbial diversity of Istrian cheese is analysed in details by culture-independent methods, such as molecular, sequencing-based assays did not allow distinguishing among Enterococcus species (E. faecalis, E. faecium and/or E. durans) or providing information on their intraspecies variability. Due to the bivalent effect of enterococci on food and human health, there is a need for their detailed characterization, not only at the species but also at the strain level. For example, strains of the species E. faecalis and E. faecium have been recognized as the most dominant species in fermented cheese (4), but also strains of the same species have been most frequently associated with the human and animal infections (13).
The purpose of this work is to identify and characterize members of the enterococcal community isolated during the ripening of Istrian cheese and to assess their role in cheese ripening as well as to select novel strains with interesting features that could be used as starter or adjunct cultures for fermented foods. Special focus is set towards the surveillance rate of indigenous cheese enterococci in simulated gastrointestinal conditions as well as detection of their antibiotic resistance and virulence traits.

\section{Materials and Methods}

\section{Raw milk and cheese sampling}

Six batches of Istrian cheese produced by different manufacturers (F1-F6) across the Istrian peninsula (Croatia) were analysed in the frame of this study. All manufacturers are part of a consortium for the preservation of the certified product Istrian cheese and are located in different areas of Istria with different microclimatic conditions, relief and vegetation. At each farm, two independent cheese samples were produced from the same batch of raw, full-cream ewe's milk in accordance with the traditional cheese making procedure (10). In brief, milk is heated up to $35^{\circ} \mathrm{C}$ prior to the addition of natural rennet. The milk coagulum is left for maximum $1 \mathrm{~h}$ at room temperature until the curd formed, which is cut into pieces and cooked at $42{ }^{\circ} \mathrm{C}$ for $5 \mathrm{~min}$ before moulding. After $2 \mathrm{~h}$ of whey drainage with self-pressing, the surfaces of cheese are covered in coarse salt (various mass fractions) and left for 2 days at room temperature. The cheese is placed in a ripening chamber at controlled but variable temperature and air humidity (up to $19^{\circ} \mathrm{C}$ and up to $90 \%$, respectively) for 90-120 days.

The cheese samples were taken with sterile cork borers ( $1 \mathrm{~cm}$ in diameter) from two individual cheese samples of each manufacturer after 30 (Ch30), 60 (Ch60), 90 (Ch90) and 120 (Ch120) days. In addition, milk (M) and cut curd (Cr) samples were taken at day zero. All samples were stored at $4{ }^{\circ} \mathrm{C}$ and analyzed within $24 \mathrm{~h}$ after sampling. The $\mathrm{pH}$ of the ripened cheese samples was 4.7 to 5.4 and their fat and salt contents ranged between 40 and 52 $\%$, and 3.4 and $4.7 \%$, respectively.

\section{Isolation of enterococci}

The milk and cheese samples were subjected to microbiological analysis for enumeration and isolation of Enterococcus species. The cheese samples were homogenized with a Stomacher ${ }^{\circledR}$ (BagMixer 400; Interscience; St Nom, France) for $3 \mathrm{~min}$ and diluted tenfold in a sterile physiological solution $(0.9 \% \mathrm{NaCl})$. Aliquots of $100 \mu \mathrm{L}$ of the three highest dilutions were inoculated on two selective kanamycin aesculin azide (KAA) agar plates (Merck, Darmstadt, Germany) and incubated under aerobic conditions at $37^{\circ} \mathrm{C}$ for $48 \mathrm{~h}$. Ten to fifteen colonies were randomly selected from the highest dilution of each sample and purified twice on KAA agar. Overall 588 isolates were collected and further analyzed. The pure cultures were characterized using the Gram stain method and catalase test. After microscopic examination, Gram-positive and catalase-negative coccoid isolates were grown overnight in $4 \mathrm{~mL}$ of brain-heart infusion (BHI) medium (Merck) 
supplemented with $20 \mu \mathrm{g} / \mathrm{mL}$ of kanamycin. One aliquot of overnight cultures was used for DNA extractions and another one was stored at $-80{ }^{\circ} \mathrm{C}$ in BHI (Merck) broth supplemented with glycerol (80:20 by volume).

\section{DNA extraction and identification at the genus and species level}

Genomic DNA from isolates was extracted from overnight BHI cultures using NucleoSpin Tissue Kit (Macherey-Nagel, Düren, Germany) according to the manufacturer's instructions. The quantity of DNA extracts was checked with a Nanodrop spectrophotometer (NanoDrop Technologies, Wilmington, DE, USA).

To determine the affiliation of isolates to genus level, PCR assay was carried out with Enterococcus genus-specific primers as described by Deasy et al. (14). A subsequent multiplex PCR reaction with E. faecalis and E. faecium species-specific primers was carried out in accordance with the PCR protocol of Dutka-Malen et al. (15). The primers are listed in Table $1(5,14-23)$. Isolates that were not assigned to Enterococcus genus were not characterized further. Enterococci that were not affiliated to $E$. faecalis or $E$. faecium species were additionally amplified and sequenced using the universal bacterial primer sets $27 \mathrm{f}$ and 1401R designed by Lane (16) and Nübel at al. (17). The PCR mixture and amplification program were as previously described by Schreiner et al. (24). The PCR products were separated on $1.5 \%$ agarose gels $(100 \mathrm{~V}, 1 \mathrm{~h})$ and purified by NucleoSpin Gel and PCR Clean-up Kit (Macherey-Nagel). PCR products were sequenced on an ABI PRISM $^{\circledR} 3730$ DNA Sequencer (Applied Biosystems, Foster City, CA, USA) using a BigDye Terminator v. 3.1 Cycle Sequencing Kit (Applied Biosystems). Reaction conditions and thermal cycle program were as previously described by Mrkonjić Fuka et al. (25). Unincorporated dye terminators were removed by ethanol precipitation.

\section{Fingerprinting of Enterococcus spp.}

For a strain-specific characterization, PCR assay based on randomly amplified polymorphic DNA (RAPD) was used. Amplification reactions were performed in a $25-\mu \mathrm{L}$ reaction volume containing $50 \mathrm{ng}$ of template DNA, 1× PCR buffer, $0.1 \mathrm{mM}$ dNTP, $1.5 \mathrm{mM} \mathrm{MgCl}, 2 \mu \mathrm{M}$ primer and $1.25 \mathrm{U}$ of Taq DNA polymerase (Invitrogen, Thermo Fisher Scientific, Waltham, MA, USA). The used primers (M13, D8635 and P2) are listed in Table 1. Thermal cycler was programmed to: initial denaturation at $94^{\circ} \mathrm{C}$ for $30 \mathrm{~s}$, $94{ }^{\circ} \mathrm{C}$ for $5 \mathrm{~min}$ for complete denaturation, $37^{\circ} \mathrm{C}$ for $5 \mathrm{~min}$ for low stringency annealing and $72{ }^{\circ} \mathrm{C}$ for $5 \mathrm{~min}$ for extension for 2 cycles. This was followed by 40 cycles of 1 min at $94{ }^{\circ} \mathrm{C}, 1 \mathrm{~min}$ at $37^{\circ} \mathrm{C}, 2 \mathrm{~min}$ at $72{ }^{\circ} \mathrm{C}$. Final extension was programmed at $72{ }^{\circ} \mathrm{C}$ for $10 \mathrm{~min}$. Amplified PCR products were separated by electrophoresis on $2.5 \%$ (by mass per volume) agarose gels. Clustering was carried out in Bionumerics v. 7.6 software platform (26) using the unweighted pair group method with arithmetic average (UPGMA) clustering algorithm (27) and band-based Dice correlation coefficient for creating the similarity matrix. Based on their RAPD-PCR pattern, representative strains were selected and tested for further phenotypic, technological and safety properties. Monophyletic groups were omitted from further analysis.

\section{Acidifying activity and tolerance to different environ- mental conditions}

Overall 35 representative strains were tested for their acidifying activity. The differences in the $\mathrm{pH}$ were measured after 2,6 and $24 \mathrm{~h}$ of incubation at $37^{\circ} \mathrm{C}$ using a pH-meter. Combined pH electrodes (InPro ${ }^{\oplus} 3030$; Metter Toledo, Greifensee, Switzerland) were standardized using two buffers $(\mathrm{pH}=4.0$ and 7.0) and disinfected after each run using a $3 \% \mathrm{HCl}$ solution. Strains were inoculated in duplicates at a level of $2 \%$ in reconstituted sterile nonfat dry milk ( $10 \%$ by mass per volume; Fluka, Sigma-Aldrich, St. Louis, MO, USA). The acidification rate (as $\Delta \mathrm{pH})$ was calculated according to Jamalay et al. (28):

$$
\Delta \mathrm{pH}=\mathrm{pH}_{\text {initial }}-\mathrm{pH}_{\text {final }}
$$

The ability of representative strains to grow at 10 and $45^{\circ} \mathrm{C}$, in 4 and $6.5 \% \mathrm{NaCl}$ and at $\mathrm{pH}=4$ and 9.6 was tested in duplicates in BHI broth and recorded after $72 \mathrm{~h}$ of growth at $37^{\circ} \mathrm{C}$.

\section{Lipolysis, haemolysis, caseinolytic and proteolytic activity}

For screening of lipolytic and caseinolytic activity, the representative strains were cultured overnight at $37^{\circ} \mathrm{C}$ in BHI broth. Overnight cultures were subcultured in fresh BHI broth and grown until an absorbance $(A)$ of 0.3 was achieved. A volume of $10 \mu \mathrm{L}$ of cultures was transferred on sterile cellulose discs (Biorad, Berkeley, CA, USA) previously placed on Tributyrin Agar (Oxoid LTD, Basingstoke, UK) to screen for lipolytic activity, or on BHI agar containing $1.5 \%$ of skimmed milk for caseinolytic activity. Plates were incubated for 3 days at $30{ }^{\circ} \mathrm{C}$ for lipolytic or at $37^{\circ} \mathrm{C}$ for caseinolytic activity and observed daily for halo formation around the discs. The radius of the halo formation (in $\mathrm{mm}$ ) at the end of incubation was used as measure of the lipolytic or caseinolytic activity. The sizes of clear zones (including the diameter of disk) on the agar surface around the discs were measured in $\mathrm{mm}$ and expressed as - (no halo observed or less than $10 \mathrm{~mm}$ ) or + $(\geq 10 \mathrm{~mm})$. The haemolysis was tested by streaking overnight cultures on BHI agar plates containing $5 \%$ cow's blood. The plates were incubated for $72 \mathrm{~h}$ at $37^{\circ} \mathrm{C}$. Zones of clearing around colonies indicated haemolysin production. Proteolytic activity was evaluated by the addition of chromogenic peptide N-succinyl-Ala-Ala-Pro-Phe $p$-nitroanilide (S-Ala, Sigma-Aldrich). Release of $p$-nitroanilide $(p N A)$ by the action of enterococcal proteinase is measured at $410 \mathrm{~nm}$ as described by Savoy de Giori and Hébert (29). Results were expressed in $\mu \mathrm{M}$ of $p \mathrm{NA}$.

\section{Survival in simulated gut conditions and autoaggregation assay}

To estimate the transit tolerance through a simulated in vitro digestion, all representative enterococcal strains were tested as described by Doleyres et al. (30) and Nueno-Palop and Narbad (31) with slight modifications. To simulate the possible hydrolysis of bacteria in the oral cavity, enterococcal strains were grown overnight in skimmed milk ( $10 \%$, by mass per volume) and diluted 1:10 in phosphate-buffered saline (PBS), after which lys- 
Table 1. List of primers used in this study

\begin{tabular}{|c|c|c|c|c|}
\hline Primer & Composition $\left(5^{\prime}-3^{\prime}\right)$ & PCR product/bp & Reference & Target gene/group \\
\hline$\overline{D d l 1}$ & ATCAAGTACAGTTAGTCT & \multirow{2}{*}{941} & \multirow{4}{*}{$(15)$} & \multirow{2}{*}{ ddl/E. faecalis } \\
\hline $\operatorname{Ddl} 2$ & ACGATTCAAAGCTAACTG & & & \\
\hline Ddl3 & TAGAGACATTGAATATGCC & \multirow{2}{*}{550} & & \multirow[t]{2}{*}{ ddl/E. faecium } \\
\hline Ddl4 & TCGAATGTGCTACAATC & & & \\
\hline E1 & TCAACCGGGGAGGGT & \multirow{2}{*}{733} & \multirow{2}{*}{ (14) } & \multirow{2}{*}{ 16S rRNA/Enterococcus } \\
\hline E2 & ATTACTAGCGATTCCGG & & & \\
\hline $27 \mathrm{~F}$ & AGAGTTTGATCMTGGCTCAG & \multirow[t]{2}{*}{1374} & $(16)$ & \multirow{2}{*}{$16 \mathrm{~S}$ rRNA/bacteria } \\
\hline $1401 \mathrm{R}$ & CGGTGTGTACAAGACCC & & $(17)$ & \\
\hline M13 & GAGGGTGGCGGTTCT & varying & $(18)$ & willing \\
\hline $\mathrm{P} 2$ & GATCGGACGG & varying & (19) & willing \\
\hline D8635 & GAGCGGCCAAAGGGAGCAGAC & varying & $(20)$ & willing \\
\hline \multirow{2}{*}{ tetK } & TCGATAGGAACAGCAGTA & \multirow{2}{*}{169} & \multirow[b]{2}{*}{$(21)$} & \multirow[b]{2}{*}{ tetK } \\
\hline & CAGCAGATCCTACTCCTT & & & \\
\hline \multirow{2}{*}{ tetL } & TCGTTAGCGTGCTGTCATTC & \multirow{2}{*}{267} & \multirow{2}{*}{$(22)$} & \multirow{2}{*}{ tet $L$} \\
\hline & GTATCCCACCAATGTAGCCG & & & \\
\hline \multirow{2}{*}{ tetM } & GTGGACAAAGGTACAACGAG & \multirow{2}{*}{406} & \multirow{2}{*}{$(21)$} & \multirow{2}{*}{ tet $M$} \\
\hline & CGGTAAAGTTCGTCACACAC & & & \\
\hline \multirow{2}{*}{ tetO } & AACTTAGGCATTCTGGCTCAC & \multirow{2}{*}{515} & & \multirow{2}{*}{ tetO } \\
\hline & TCCCACTGTTCCATATCGTCA & & & \\
\hline & CATAGACAAGCCGTTGACC & & (22) & \\
\hline tetS & ATGTTTTTGGAACGCCAGAG & 667 & & tets \\
\hline & TCTAAAAAGCATGTAAAAGAA & & & \\
\hline ermA & CTTCGATAGTTTATTAATATTAGT & 645 & (23) & erm \\
\hline TE 3 & AAGAAAAAGTAGACCAAC & & & \\
\hline TE 4 & AACGGCAAGACAAGTAAATA & 1553 & & agg \\
\hline TE 5 & GACAGACCCTCACGAATA & & & \\
\hline TE 6 & AGTTCATCATGCTGCTGTAGTA & 705 & & efaAfs \\
\hline TE 9 & ACCCCGTATCATTGGTTT & & & \\
\hline TE 10 & ACGCATTGCTTTTCCATC & 419 & & gelE \\
\hline TE 13 & CTGATGGAAAGAAGATAGTAT & & & \\
\hline TE 14 & TGAGTTGGTCTGATTACATTT & 742 & & cylM \\
\hline TE 15 & ATTCСТACСТATGTTCTGTTA & & & \\
\hline TE 16 & AАТАААСТСТТСТТТТССААС & 843 & $(5)$ & cylB \\
\hline TE 17 & TGGATGATAGTGATAGGAAGT & & & \\
\hline TE 18 & TCTACAGTAAATCTTTCGTCA & 517 & & cylA \\
\hline TE 34 & TTGCTAATGCTAGTCCACGACC & & & \\
\hline TE 36 & GCGTCAACACTTGCATTGCCGAA & 933 & & esp \\
\hline TE 37 & AACAGATCCGCATGAATA & & & \\
\hline TE 38 & CATTTCATCATCTGATAGTA & 735 & & efaAfm \\
\hline TE 49 & AACATTCAGCAAACAAAGC & & & \\
\hline TE 50 & TTGTCATAAAGAGTGGTCAT & 1405 & & $\mathrm{cob}$ \\
\hline TE 51 & TGGTGGGTTATTTTTCAATTC & & & \\
\hline TE 52 & TACGGCTCTGGCTTACTA & 782 & & cpd \\
\hline
\end{tabular}

ozyme (Sigma-Aldrich) was added to a final concentration of $100 \mathrm{mg} / \mathrm{L}$. Samples were then incubated for $5 \mathrm{~min}$ at $37^{\circ} \mathrm{C}$. In order to estimate the cell survival rate in simulated gastric and intestinal conditions, overnight enterococcal cultures $(1 \mathrm{~mL})$ were harvested by centrifugation (Eppendorf 5415R; Eppendorf, Hamburg, Germany) at $10000 \times g$ for $10 \mathrm{~min}$ at room temperature. The pellets were washed twice with $0.1 \%$ peptone water, resuspended in $100 \mu \mathrm{L}$ of $0.1 \%$ peptone and stored on ice until use. To simulate the gastric digestion, $0.5 \% \mathrm{NaCl}$ and $0.3 \%$ pepsin solution (Sigma-Aldrich) were used. The samples were adjusted to $\mathrm{pH}=2.5$ (with $1 \mathrm{~mol} / \mathrm{L}$ of $\mathrm{HCl}$ ). The solu- 
tion containing $270 \mu \mathrm{L}$ of simulated gastric juices and 30 $\mu \mathrm{L}$ of cell suspension was mixed and incubated at $37^{\circ} \mathrm{C}$ for $30 \mathrm{~min}$. For cell survival in simulated intestinal conditions, $270 \mu \mathrm{L}$ of $0.4 \%$ bile salts and $0.2 \%$ pancreatin solution (Sigma-Aldrich) were mixed with $30 \mu \mathrm{L}$ of cell suspension and incubated for $30 \mathrm{~min}$ at $37^{\circ} \mathrm{C}$. Samples were removed for determination of cell counts before and after oral, gastric and intestinal digestion. Aliquots were serially diluted in PBS buffer $(\mathrm{pH}=7.2)$ and viable counts were determined after incubation at $37^{\circ} \mathrm{C}$ for $48 \mathrm{~h}$. Each strain was tested twice on BHI agar.

Autoaggregation assay was performed according to Fortina et al. (32) and Del Re et al. (33) with slight modifications. Aggregation was evaluated using $4 \mathrm{~mL}$ of cell suspension corresponding to viable counts of approx. $10^{8}$ $\mathrm{CFU} / \mathrm{mL}$. The cell suspension was vortexed for $10 \mathrm{~s}$. The absorbance $(A)$ was measured at $610 \mathrm{~nm}$ after 3 and $5 \mathrm{~h}$ of incubation at room temperature. The aggregation percentage was expressed as:

\section{Aggregation=1- $\left(A_{\mathrm{t}} / A_{0}\right) \cdot 100$}

where $A_{\mathrm{t}}$ represents the absorbance measured at $610 \mathrm{~nm}$ at time $t=3$ and $5 \mathrm{~h}$, and $A_{0}$ the absorbance at $t=0$.

\section{Phenotypic characterization of antibiotic susceptibility}

Antimicrobial susceptibility was determined by standardized agar diffusion test using BBL ${ }^{\mathrm{TM}}$ Sensi-Disc ${ }^{\mathrm{TM}}$ antimicrobial susceptibility test discs (Becton, Dickinson and Company, Le Pont de Claix, France). The discs impregnated with specific concentrations of antimicrobial agents were placed onto Mueller-Hinton ( $\mathrm{MH}$, Merck) agar plates seeded with representative strains at the concentration of $1 \mathrm{McF}$ arland standard. The plates were incubated for $18 \mathrm{~h}$ at $35^{\circ} \mathrm{C}$ under aerobic conditions. All representative isolates were screened for their susceptibility to penicillin $\mathrm{G}(10 \mathrm{U})$, ampicillin $(10 \mu \mathrm{g})$, tetracycline (5 and 30 $\mu \mathrm{g})$, vancomycin $(5 \mu \mathrm{g})$, streptomycin $(10 \mu \mathrm{g})$, erythromycin $(5$ and $15 \mu \mathrm{g})$, chloramphenicol $(10 \mu \mathrm{g})$, rifampicin (5 $\mu \mathrm{g})$, clindamycin $(2$ and $10 \mu \mathrm{g})$ and ampicillin/sulbactam $(20 \mu \mathrm{g})$ (Becton, Dickinson and Company). After incubation, each strain was classified as sensitive, intermediate or resistant following the recommendations of the $\mathrm{Na}$ tional Committee for Clinical Laboratory Standards (34).

\section{Detection of antibiotic resistance genes}

Detection of the genes responsible for resistance to tetracycline (tet $K$, tet $L$, tet $M$, tet $O$ and tet $S)$, vancomycin (van $A$ and $v a n B$ ) and erythromycin (ermA and ermB) was investigated for all strains exhibiting the respective phenotypic resistance pattern by specific PCR assays. Primers used are listed in Table 1. The DNA amplification was performed according to $\mathrm{Ng}$ et al. (22) and Sutcliffe et al. (23) in $25 \mu \mathrm{L}$ of reaction mixture containing $100 \mathrm{ng}$ of DNA template. The amplified PCR products were visualized on $1.5 \%$ agarose gel after staining with ethidium bromide.

\section{PCR detection of genes coding for virulence factors}

The indices of genes encoding for following virulence factors were investigated: aggregation substance ( $a g g)$, gela- tinase (gelE), cytolysin (cylM, cylB), cytolysin activator (cylA), enterococcal surface protein (esp), cell wall adhesin (efaAfs from $E$. faecalis and efaAfm from E. faecium) and sex pheromones (cpd and $c o b)$. PCR amplification was performed with primers and conditions described by Eaton and Gasson (5), except for cob and agg genes, whose 29 cycles of elongation were prolonged to $45 \mathrm{~s}$ as described by Čanžek Majhenić et al. (35). The primers are listed in Table 1.

\section{Statistical analysis}

Statistical analysis was performed using the R software programming language and $\mathrm{R}$ software environment for statistical computing (36). The level of significance was $\mathrm{p}<0.05$. Student's $t$-test was used to determine whether there were significant differences in results when E. faecalis and E. faecium were compared. Post hoc Tukey's honestly significant difference (HSD) test was used to ascertain whether there were significant differences between the results of samples from different stages of cheese manufacturing and ripening.

\section{Results and Discussion}

\section{Enumeration and identification of enterococci}

Despite the available data in other countries, studies on prevalence and safety issue of enterococci in spontaneously fermented cheese in Croatia are limited. In order to improve the knowledge on the role of enterococci in the cheese ripening process and their possible influence on public health as well as to select for potential adjunct/ starter cultures, total viable count and isolation of enterococci from 6 different farms during the ripening of Istrian cheese were carried out. The lowest count of enterococci was noticed, as expected, in milk ((3.65 \pm 2.93$) \log$ CFU/ $\mathrm{mL})$ and after 30 days of ripening it reached the maximum value ((7.96 \pm 0.80$) \log \mathrm{CFU} / \mathrm{g})$. Afterwards, the number was 10-fold lower and remained stable until 90 days of ripening. At the end of ripening (120 days) the average number of enterococci was (6.21 \pm 0.98$) \log$ CFU/g (Fig. 1).

As nowadays Istrian cheese is rarely ripened for 120 days and it is mostly sold and consumed during the first two months, the average load of enterococci within that ripening period is almost $10^{8} \mathrm{CFU} / \mathrm{g}$, exceeding the limit of maximum $10^{6} \mathrm{CFU} / \mathrm{g}$ recommended by International Commission on Microbiological Specifications for Foods

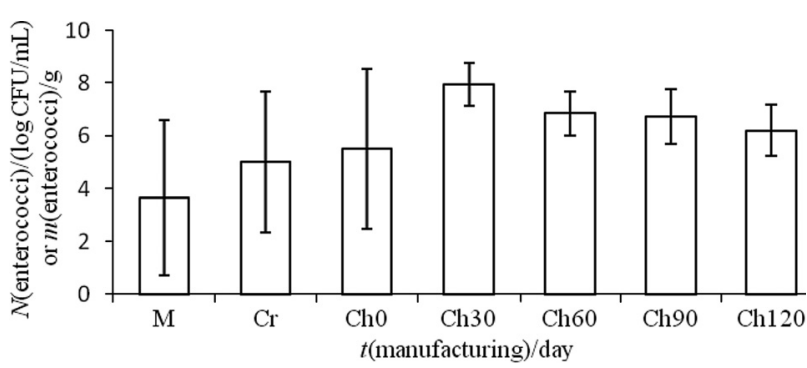

Fig. 1. Number of enterococci during manufacturing and ripening of Croatian artisan raw milk cheese. Results are expressed as mean value \pm standard deviation. Milk $(\mathrm{M})$ and curd $(\mathrm{Cr})$ samples were taken at $t=0$, and cheese samples were taken at t=30 (Ch 30), 60 (Ch 60), 90 (Ch 90) and 120 (Ch 120) days 
(37). The number of enterococci higher than $10^{6} \mathrm{CFU} / \mathrm{g}$ and even up to $10^{8} \mathrm{CFU} / \mathrm{g}$ has often been reported in different raw milk products $(9,38)$ and in some cases irrespective of raw milk or pasteurized/thermally treated milk cheese (8).

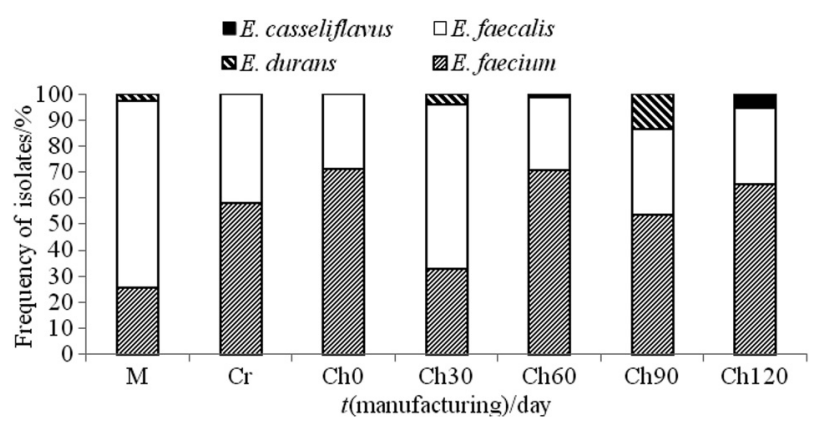

Fig. 2. Frequency of Enterococcus species isolated during manufacturing and ripening of Croatian raw milk cheese obtained from six different farms (F1-F6) based on PCR identification at the species level (E. faecalis and E. faecium) or 16S rRNA gene sequencing (E. casseliflavus and E. durans). Milk (M) and curd (Cr) samples were taken at $t=0$, and cheese samples were taken at $t=30$ (Ch30), 60 (Ch60), 90 (Ch90) and 120 (Ch120) days
As particular species in the same microbial group, or even the particular strain of a given species specifically affect the organoleptic profile of the final product and may have unique technological or safety traits, a total of 588 presumptive enterococci isolated from KAA agar in this study were identified by PCR-based approach to the genus, species and strain level. In PCR reaction with genus-specific primers, $92.19 \%$ of isolates were confirmed as Enterococcus members (data not shown). PCR identification at the species level identified $53.8 \%$ of Enterococcus isolates as E. faecium and $42.4 \%$ as E. faecalis (Fig. 2). They were found at the high level in all samples and their presence remained stable during the fermentation and ripening. The predominance of E. faecium and E. faecalis over other enterococci is in agreement with other studies on artisan cheese, where high abundance of these two species has been reported (1). E. durans and E. casseliflavus were identified based on the sequencing of 16S rRNA gene and were detected in much lower percentage (2.84 and $0.95 \%$ respectively).

The genetic diversity of the identified species was analyzed by RAPD-PCR-based fingerprinting (Fig. 3). The RAPD-PCR allowed detailed characterization of isolates at the strain (ecotype) level. Thus, we used this approach
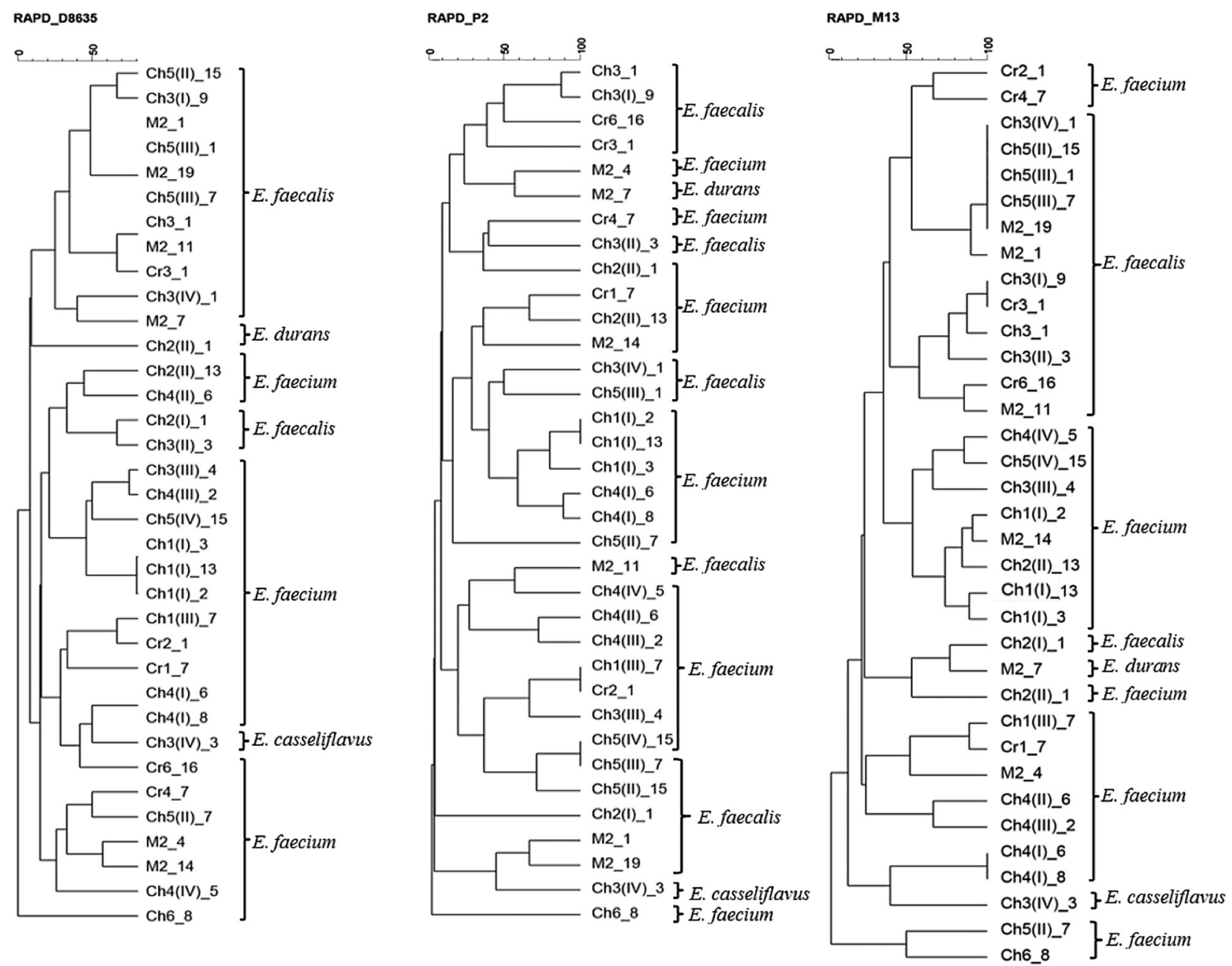

Fig. 3. Dendrograms based on a statistical analysis of the RAPD-PCR fingerprints, obtained using three different primers (D8635, P2 and M13) 
to select representative strains for further technological and safety analysis. RAPD-PCR fingerprinting based on M13, D8635 and P2 primers discriminated 35 clusters that comprised two or more isolates. From each of these clusters, one representative strain was selected and further analyzed (a total of 35 strains). The enterococcal isolates $(2.4 \%)$ that displayed unique banding patterns were omitted from further analysis. Although the same distribution profile of Enterococcus species was noticed among six farms in this study, most of the detected genotypes were farm specific. Of 35 detected genotypes, five dominant ones (approx. $30 \%$ of total isolates) were shared among the farms. Such a genotype distribution reflected the particular differences in traditional Istrian cheese production. Mainly, variable salt concentration, ripening temperature and air humidity as well as microclimatic or vegetation conditions may be the reason for specific strain distribution.

\section{Phenotypic characterization and biotechnological properties of selected strains}

During cheese manufacturing, lactic acid bacteria are exposed to different temperatures, $\mathrm{pH}$ and salt concentration. The recovery and persistence of enterococci in some types of cheese during ripening can be attributed to their wide range of growth temperatures and their tolerance to $\mathrm{pH}$ and salt (3). All 35 representative strains tested in this study were able to grow at 10 and $45^{\circ} \mathrm{C}$ in the presence of 4 and $6.5 \% \mathrm{NaCl}$ as well as at $\mathrm{pH}=5$ and 9.6, which is in line with the high adaptability of enterococci to harsh environmental conditions.

A rapid decrease of milk $\mathrm{pH}$ is essential for coagulation and is therefore a crucial step in the cheese manufacturing process. In general, the investigated strains in this study showed low acidifying activity. None of the isolates were able to reduce the milk $\mathrm{pH}$ by more than 1.51 units even after $24 \mathrm{~h}$ of incubation (Table 2). Only three strains belonging to E. faecalis, one E. faecium, one E. casseliflavus and one E. durans strain $(19.4,0.38,0.95$ and $2.84 \%$ of total identified enterococci) were able to lower the $\mathrm{pH}$ of $10 \%$ skimmed milk below $\mathrm{pH}=5$ (initial $\mathrm{pH}=6.33$ ). No significant differences were found between $E$. faecalis and E. faecium strains after 2 and 6 h of incubation, whereas after 24 $\mathrm{h}$ E. faecalis strains exhibited better acidifying potential by lowering the $\mathrm{pH}$ of the milk by 1.09 units on average, while E. faecium lowered the $\mathrm{pH}$ of the milk by 0.87 units $(p<0.01)$ on average. The poor acid production by enterococci has also been noticed in other studies and most strains reduce the $\mathrm{pH}$ of the milk by only $0.4-0.8$ units. Likewise, in our study, overall better acidification properties of E. faecalis strains than other enterococcal species were found $(39,40)$.

Although isolates that show low acidification capacity are not ideal candidates for use as part of starter cultures, such strains can take part in the development of flavour and texture, by proteolytic and lipolytic activity or as bioprotective cultures by producing antimicrobial substances.

The degradation of proteins and lipids plays an important role in the development of texture and taste of the cheese. Almost $40 \%$ of tested enterococci in our study showed caseinolytic activity and lipolytic activity of nearly one third of strains $(28.60 \%)$ was measured by agar disc diffusion method (Table 2). Sarantinopoulos et al. (39) demonstrated the ability of majority of 129 enterococal species isolated from diverse environments to hydrolyse tributyrin and as such to be presumably involved in lipid conversion during the cheese maturation.

Overall, E. faecium strains had higher caseinolytic activity than E. faecalis and for lipolytic activity opposite trend was noticed. With regard to peptidase activity, as a result of measuring the amount of $p$ NA released from the chromogenic peptide (S-Ala), E. faecalis had significantly higher $(\mathrm{p}<0.01)$ activity than E. faecium (6641.91 and $6028.90 \mu \mathrm{M}$, respectively). It seems that E. faecium isolates from Istrian cheese are mainly involved in casein degradation, whereas lipolysis and peptidase activity are mainly due to the activity of E. faecalis strains, at least under the applied laboratory conditions.

\section{Surveillance in simulated gut conditions}

The ability of entereococcal strains to survive in the GI tract and their autoaggregation ability were tested in order to evaluate their colonization potential and passage through the GI tract, which is a prerequisite for the estimation of their possible influence on human health and their use as probiotics.

The 35 representative enterococci tested in this study were lysed in varying percentage in the conditions of human oral cavity, in the acidic environment of the stomach and in the intestinal conditions (Table 2). The survival rate in the first barrier (human oral cavity) was between 38.52 and $98.30 \%$ (on average $58.68 \%$ ). Although low pH and antimicrobial activity of pepsin are known to be very effective in decreasing viability of bacteria, survival rates of the tested strains in simulated environment of the stomach ( $\mathrm{pH}=2$ and presence of pepsin) were higher than in the conditions of human oral cavity, and was on average $75.45 \%$ (3.19-99.32\%). While the pH of the small intestine is more favourable for bacterial survival, the presence of pancreatin and bile salts may have detrimental effect. In simulated intestinal conditions (bile salts and pancreatin), survival rate among the tested strains was between 2.75-95.95\% (on average 55.58 \%).

Significant differences in the ability to survive in simulated GI tract conditions were noted among Enterococcus species and among the strains of the same species (Table 2). E. faecalis showed higher survival rate in the conditions of human oral cavity than E. faecium ( $<<0.01)$, while E. faecium showed higher survival rate in gastric conditions $(p<0.01)$. These findings are in agreement with those reported by other authors for E. faecium probiotic strains that show higher resistance to low $\mathrm{pH}$ than other enterococci (41). No significant differences were found between the survival rates of E. faecalis and E. faecium in intestinal conditions.

All tested strains exhibited poor autoaggregation ability, with values after $5 \mathrm{~h}$ ranging from 4.64 to $46.66 \%$ (on average $13.22 \%$ ), therefore exhibiting low capacity of adhesiveness. 


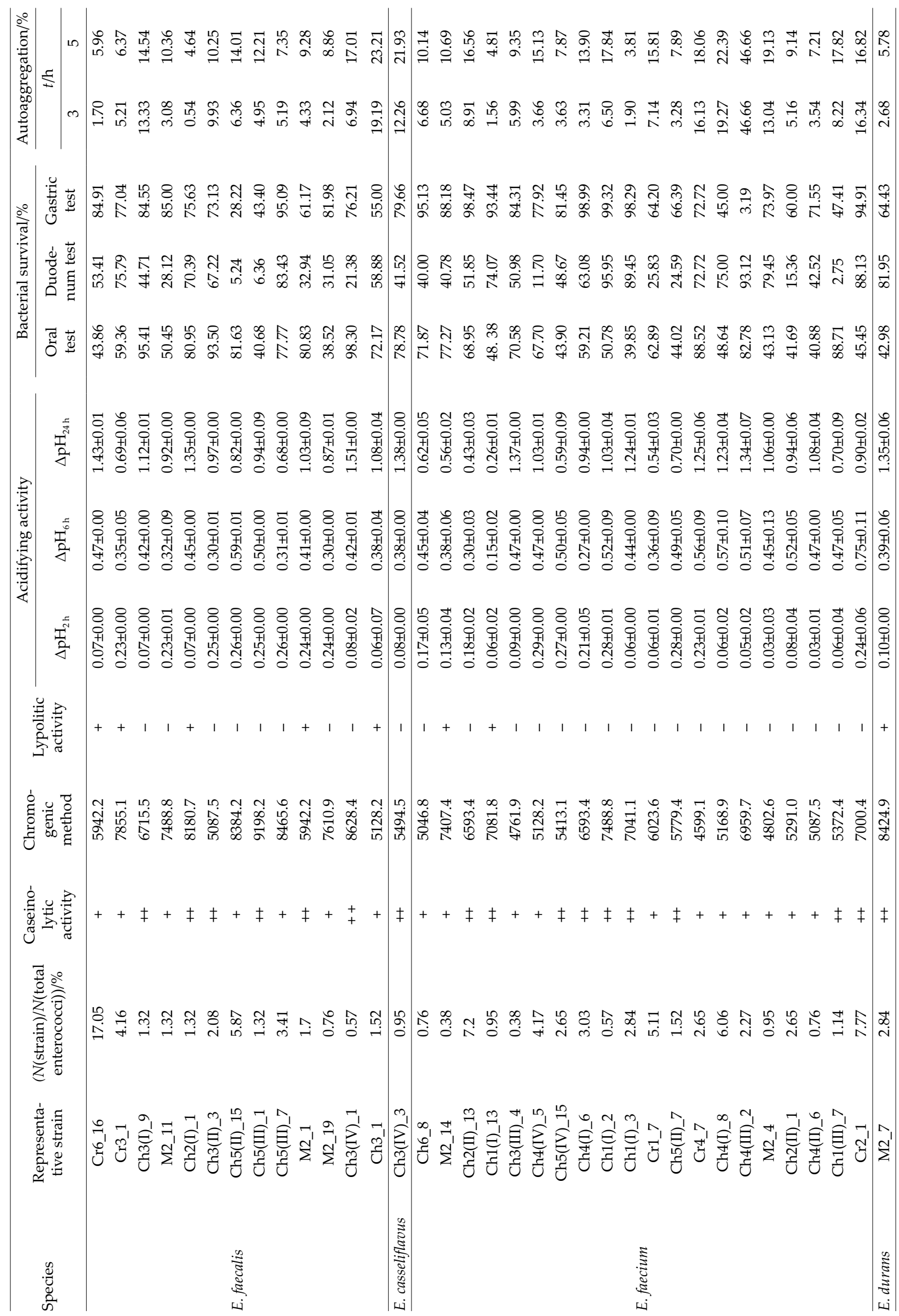




\section{Safety issues}

Enterococci in food of animal origin have been shown to harbour different virulence factors, suggesting that this type of food could act as an important environmental reservoir for human infections. The presence of 10 genes coding for virulence factors and potential pathogenicity of enterococcal strains was evaluated by PCR (Table 3). Many of virulence genes, e.g. aggregation substances, cytolysin and gelatinase genes are known to have a silent state, making their genotypic study more reliable than phenotyping one because they might remain undetected under the in vitro conditions but be expressed in vivo, so the pathogenic potential of such strains might be underestimated (42).
PCR amplification of the aggregation substance (agg) and surface protein (esp) genes revealed 27.65 and $9.85 \%$ of positive strains in the current study. The esp gene is known to be associated with the biofilm production, endocarditis and nosocomial infections and is usually detected at low frequency $(43,44)$, quite opposite to a study of Semedo et al. (45) who detected $62 \%$ of esp-positive strains, $57 \%$ of which being of food origin versus $22 \%$ from clinical samples $(N=164)$.

Virulence traits involved in the production of the cytolysin ( $c y l A, c y l B$ and $c y l M)$ are one of the most studied virulence traits associated with enterococci and are usually detected in low number of isolates (46). Of all entero-

Table 3. Detection of virulence determinants

\begin{tabular}{|c|c|c|c|c|c|c|c|c|c|c|c|c|}
\hline \multirow{2}{*}{ Species } & \multirow{2}{*}{$\begin{array}{l}\text { Representative } \\
\text { strain }\end{array}$} & \multirow{2}{*}{$\begin{array}{l}(N(\text { strain }) / N(\text { total } \\
\text { enterococci })) / \%\end{array}$} & \multicolumn{10}{|c|}{ Virulence determinant } \\
\hline & & & $a g g$ & $e f a A f s$ & cylM & cylA & esp & efaAfm & $c o b$ & gelE & cylB & $c p d$ \\
\hline \multirow{13}{*}{ E.faecalis } & Cr6_16 & 17.05 & + & + & + & + & - & + & + & + & - & + \\
\hline & Cr3_1 & 4.16 & - & + & + & - & - & + & + & + & - & + \\
\hline & Ch3(I)_9 & 1.32 & - & + & + & - & + & + & + & + & - & + \\
\hline & M2_11 & 1.32 & + & + & + & + & + & + & + & + & - & + \\
\hline & Ch2(I)_1 & 1.32 & - & + & + & - & + & + & + & + & - & + \\
\hline & Ch3(II)_3 & 2.08 & - & + & - & - & + & + & + & - & - & + \\
\hline & Ch5(II)_15 & 5.87 & + & + & - & - & - & - & + & - & - & + \\
\hline & Ch5(III)_1 & 1.32 & - & + & - & - & + & - & + & - & - & + \\
\hline & Ch5(III)_7 & 3.41 & - & + & - & - & - & - & + & - & + & + \\
\hline & M2_1 & 1.7 & - & + & - & - & + & + & + & + & + & + \\
\hline & M2_19 & 0.76 & - & + & - & - & + & + & + & + & - & + \\
\hline & Ch3(IV)_1 & 0.57 & - & + & - & - & - & + & + & - & - & + \\
\hline & Ch3_1 & 1.52 & - & + & + & + & - & - & - & + & + & + \\
\hline E. casseliflavus & Ch3(IV)_3 & 0.95 & - & - & - & - & - & + & - & + & - & + \\
\hline \multirow{20}{*}{ E. faecium } & Ch6_8 & 0.76 & + & + & - & - & - & - & - & + & + & + \\
\hline & M2_14 & 0.38 & - & + & - & - & - & - & - & + & + & + \\
\hline & Ch2(II)_13 & 7.2 & - & - & + & - & - & + & - & - & - & - \\
\hline & Ch1(I)_13 & 0.95 & - & + & - & - & - & + & - & - & - & - \\
\hline & Ch3(III)_4 & 0.38 & - & - & - & - & - & - & - & - & - & - \\
\hline & Ch4(IV)_5 & 4.17 & - & - & - & - & - & + & - & - & - & - \\
\hline & Ch5(IV)_15 & 2.65 & - & - & - & - & - & + & - & - & - & - \\
\hline & Ch4(I)_6 & 3.03 & - & + & + & - & - & + & - & + & - & + \\
\hline & Ch1(I)_2 & 0.57 & - & + & - & - & - & + & - & + & + & + \\
\hline & Ch1(I)_3 & 2.84 & - & + & + & - & - & + & - & + & + & + \\
\hline & Cr1_7 & 5.11 & - & + & + & - & - & + & - & - & - & - \\
\hline & Ch5(II)_7 & 1.52 & - & + & - & - & - & - & + & - & + & + \\
\hline & Cr4_7 & 2.65 & + & + & + & - & - & + & - & + & + & + \\
\hline & Ch4(I)_8 & 6.06 & - & + & - & - & - & + & + & - & - & + \\
\hline & Ch4(III)_2 & 2.27 & - & - & - & - & - & + & - & - & - & - \\
\hline & M2_4 & 0.95 & - & + & + & - & - & - & - & - & - & - \\
\hline & Ch2(II)_1 & 2.65 & - & + & + & - & - & - & - & - & - & - \\
\hline & Ch4(II)_6 & 0.76 & - & - & - & - & - & + & - & - & - & - \\
\hline & Ch1(III)_7 & 1.14 & - & - & - & - & - & + & - & - & - & - \\
\hline & $\mathrm{Cr} 2 \_1$ & 7.77 & - & + & - & - & - & + & - & - & - & - \\
\hline E. durans & M2_7 & 2.84 & - & - & - & - & - & + & - & - & - & - \\
\hline
\end{tabular}


cocci from Istrian cheese, cytolysin components (cylM, cylB and $c y l A$ ) were present in $51.14,15.34$ and $19.88 \%$ of strains respectively, which is high in comparison with other studies $(44,46)$.

The genes gelE and $c p d$, associated with toxin production and sex pheromones, were also reported to be commonly found in commensal isolates (31). The sex pheromone determinants $c p d$ and $c o b$ occurred with the frequency of 61.17 and $48.48 \%$ respectively and gelatinase (gelE) gene was present in $40.34 \%$ of our enterococcal isolates.

The widespread occurrence of adhesion-associated protein in enterococci, irrespective of origin and species allocation, is reported in many food and clinical isolates (45) and was confirmed in our study with $77.65 \%$ efaAfsand $81.25 \%$ efaAfm-positive enterococci.

Overall, E. faecalis strains harboured $56.70 \%$ more virulence genes than the tested E. faecium strains. Especially high incidence of sex pheromone ( $c p d$ and $c o b$ ) and efaAfs determinants was noticed among E. faecalis isolates (100, 99 and $100 \%$ respectively). Among E. faecium, $0.70 \%$ of strains were lacking all virulence determinants and among $34.86 \%$ of strains only one virulence gene was detected (efaAfm). The cylA and esp genes were absent from all E. faecium strains. A significantly different pattern was noticed in E. faecium isolated in our study compared to strains tested by Eaton and Gasson (5), who did not detect agg, cylM, cylB or cylA and sex pheromone genes among the analyzed E. faecium strains. Although several studies have reported agg gene only in E. faecalis $(5,47)$, in this study the presence of $a g g$ was demonstrated also in $E$. faecium. The aggregation substance $(a g g)$ promotes the conjugative transfer of sex pheromone plasmids by formation of mating aggregates between donor and recipient cells (48) and may support the strain probiotic characteristics (49).

For $c o b$ and $c p d$ genes our data are in line with the literature on E. faecalis strains; however, the respective genes were also detected among E. faecium isolates (14.08 and $33.09 \%$, respectively). The detection of sex pheromones in species other than E. faecalis is confirmed by the work of Heaton and Handwerger (50), who suggested that sex pheromone cross talk between E. faecium and E. faecalis has been established, which is also indicated in our study.

The number of virulence determinants was the highest in milk samples and was decreasing until the 30th day of cheese ripening, when it rapidly increased. After 30 days of ripening, the number of virulence determinants continued to decrease and was significantly lower $(p<0.05)$ at the end of ripening. This implies a reduction of the number of strains possessing multiple virulence genes or virulence genes in general, rather than correlation to the total number of enterococci, as in milk samples the lowest CFU count and the highest number of virulence determinants was noticed.

Although enterococci can induce haemolytic reaction, none of the 35 tested strains in this study were found to cause haemolysis.

Food that is not heat treated before consumption, e.g. spontaneously fermented cheese may contain viable antibiotic-resistant bacteria that are assumed to contribute to the transmission of antibiotic resistance genes into the GI tract. Species of the genus Enterococcus are intrinsically resistant to a wide variety of antimicrobials including cephalosporins, low levels of aminoglycosides, lincomycine and quinupristin/dalfopristin $(7,44)$. However, enterococci efficiently acquire and transmit antibiotic-resistant genes via mobile genetic elements as conjugative plasmids and transposons (51), which is pivotal in the dissemination and persistence of antimicrobial resistance in enterococci.

In the current study, only $0.76 \%$ of strains were nonresistant to any of the tested antibiotics, $7.57 \%$ of strains were resistant to one antibiotic and $7.95 \%$ of the strains were resistant to two antibiotics, while others $(83.72 \%)$ were multiresistant (Table 4$)$. None of the strains were resistant to penicillin $(10 \mu \mathrm{g})$, ampicillin $(10 \mu \mathrm{g})$ and ampicillin/sulbactam $(30 \mu \mathrm{g})$. The vast majority of strains were resistant to clindamycin ( 2 and $10 \mu \mathrm{g} ; 92.80$ and $63.07 \%$, respectively), streptomycin (10 $\mu \mathrm{g} ; 82.00 \%)$ and rifampicin ( $5 \mu \mathrm{g} ; 72.35 \%$ ), while total of $28.41 \%$ of strains were resistant to chloramphenicol $(10 \mu \mathrm{g})$. A considerable number of strains were resistant to critically important antibiotics such as tetracycline (5 and $30 \mu \mathrm{g} ; 43.56$ and $17.99 \%$, respectively), erythromycin ( 5 and $15 \mu \mathrm{g} ; 35.79$ and $29.35 \%$, respectively) and vancomycin (5 $\mu \mathrm{g} ; 23.48$ $\%)$. A high frequency of resistance to erythromycin and tetracycline in enterococci from various foods was also reported in Europe, Canada, Turkey and Tunisia $(35,52-54)$. The frequency of vancomycin-resistant enterococci in food is mostly low and varied between $0-25 \%$ (6) and higher resistance to vancomycin in our study (although of low concentration) has to be considered as vancomycin is one of the few alternatives in treating enterococcal infections.

With respect to the genes responsible for resistance to tetracycline (tet $K$, tet $L$, tet $M$, tet $O$ and tetS), vancomycin (van $A$ and $\operatorname{van} B)$ and erythromycin (ermA and $\operatorname{erm} B)$, only tet $M$ gene could be detected in the analyzed strains. The tet $M$ gene is the most frequently detected in tetracycline-resistant enterococci worldwide and it is known to be mainly based on the transfer of Tn916-type transposons (55).

\section{Conclusion}

Our study confirmed the presence of enterococci as a major part of the indigenous core microbiota of Istrian cheese during fermentation and ripening, with Enterococcus faecalis and E. faecium being the predominant species. Considerable variation between strains of the same species was recorded in their ability to exhibit a wide range of biotechnologically important traits as well to survive in gastrointestinal (GI) tract. Even though probably none of enterococcal strains were able to colonize the GI tract, they can survive in harsh GI environment to different extents. The high rate of multiresistant enterococci and high load of virulence determinants detected in our study should be taken into consideration due to the high frequencies of transmission of genes encoding for antibiotic resistance and virulence factors in GI tract. The role of enterococci in cheese ripening remains questionable, because several isolates possess virulence or antibiotic resistance genes and thus have potential of endangering 


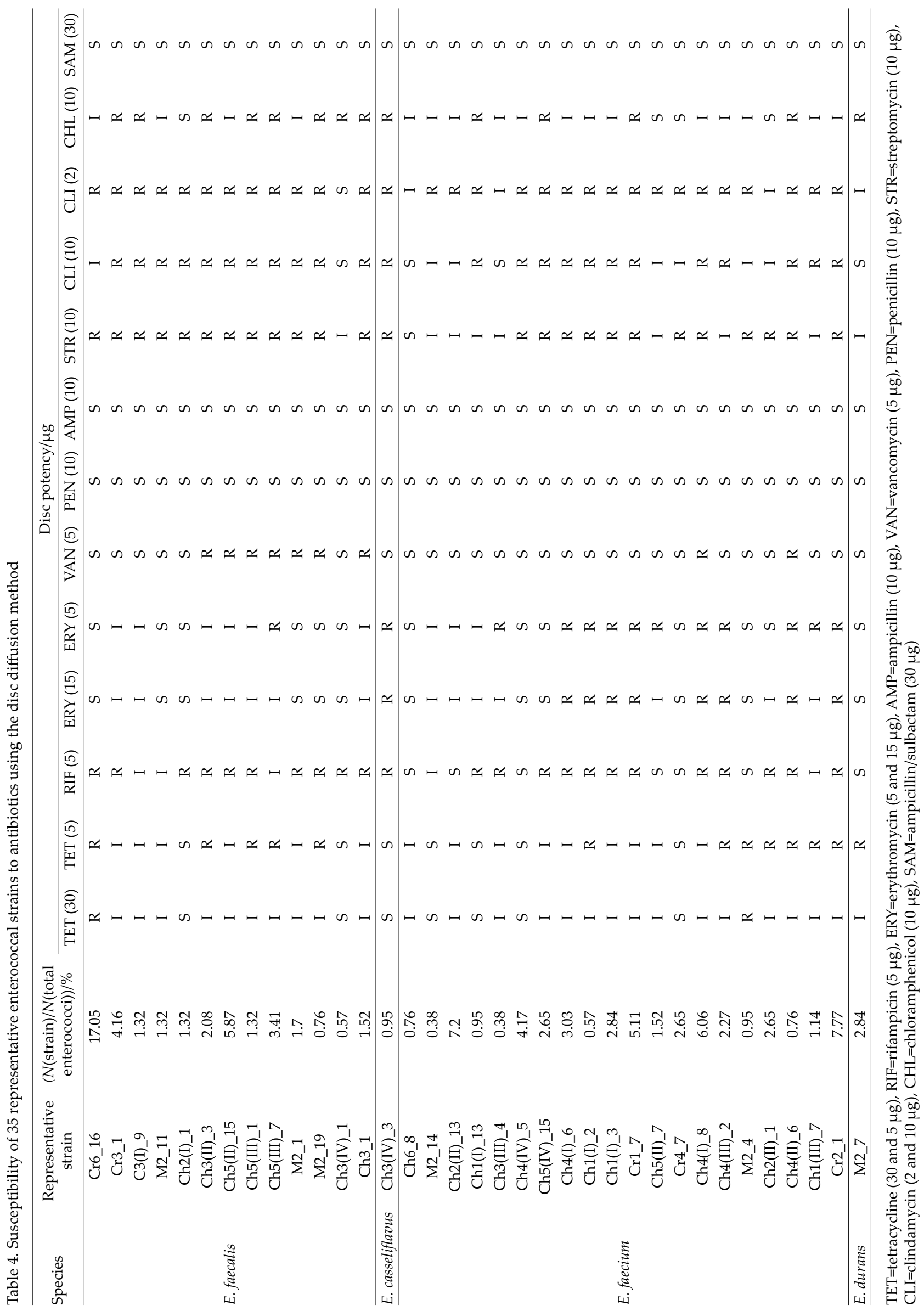


human health. In agreement with the literature, the majority of enterococci isolated from ripened Istrian cheese cannot fulfil the strict safety rules needed for starter or adjunct cultures. Based on their good technological properties, absence of most of the virulence determinants and antibiotic resistance genes, only one strain, E. durans M2_7, is a good candidate for the application as starter or adjunct culture for fermented food production.

\section{Funding}

This study was partially funded by the German Academic Exchange Service (DAAD) and the Ministry of Science and Education of the Republic of Croatia (MZO).

\section{References}

1. Franz CMAP, Holzapfel WH, Stiles ME. Enterococci at the crossroads of food safety? Int J Food Microbiol. 1999;47:1-24. https://doi.org/10.1016/S0168-1605(99)00007-0

2. Moreno MRF, Sarantinopoulos P, Tsakalidou E, De Vuyst L. The role and application of enterococci in food and health. Int J Food Microbiol. 2006;106:1-24. https://doi.org/10.1016/j.ijfoodmicro.2005.06.026

3. Giraffa G. Enterococci from foods. FEMS Microbiol Rev. 2002;26:163-71. http://doi.org/10.1111/j.1574-6976.2002.tb00608.x

4. Giraffa G. Functionality of enterococci in dairy products. Int J Food Microbiol. 2003;88:215-22. https://doi.org/10.1016/S0168-1605(03)00183-1

5. Eaton TJ, Gasson MJ. Molecular screening of Enterococcus virulence determinants and potential for genetic exchange between food and medical isolates. Appl Environ Microbiol. 2001;67:1628-35. https://doi.org/10.1128/AEM.67.4.1628-1635.2001

6. Wang JS, Muzevich K, Edmond MB, Bearman G, Stevens MP. Central nervous system infections due to vancomycinresistant enterococci: case series and review of the literature. Int J Infect Dis. 2014;25:26-31. https://doi.org/10.1016/j.ijid.2014.01.009

7. Murray BE. The life and times of the Enterococcus. Clin Microbiol Rev. 1990;3:46-65. http://doi.org/10.1128/CMR.3.1.46

8. Jamet E, Akary E, Poisson MA, Chamba JF, Bertrand X, Serror P. Prevalence and characterization of antibiotic resistant Enterococcus faecalis in French cheeses. Food Microbiol. 2012;31:191-8. https://doi.org/10.1016/j.fm.2012.03.009

9. Rehaiem A, Fhoula I, Faouzi Slim A, Ben Boubaker IB, Boudabous Chihi A, Ouzari HI. Prevalence, acquired antibiotic resistance and bacteriocin production of Enterococcus spp. isolated from Tunisian fermented food products. Food Control. 2016;63:259-66. https://doi.org/10.1016/j.foodcont.2015.11.034

10. Magdić V, Kalit S, Mrkonjić Fuka M, Skelin A, Samaržija D, Redžepović S, Havranek J. A survey on hygienic and physicochemical properties of Istrian cheese. Mljekarstvo. 2013;63: 55-63.

11. Mrkonjić Fuka M, Wallisch S, Engel M, Welzl G, Havranek J, Schloter M. Dynamics of bacterial communities during the ripening process of different Croatian cheese types derived from raw ewe's milk cheeses. PloS One. 2013;8:e80734. https://doi.org/10.1371/journal.pone.0080734

12. Mrkonjić Fuka M, Engel M, Skelin A, Redžepović S, Schloter $\mathrm{M}$. Bacterial communities associated with the production of artisanal Istrian cheese. Int J Food Microbiol. 2010;142:19-24. https://doi.org/10.1016/j.ijfoodmicro.2010.05.008

13. Mundy LM, Sahm DF, Gilmore M. Relationships between enterococcal virulence and antimicrobial resistance. Clin Microbiol Rev. 2000;13:513-22. https://doi.org/10.1128/CMR.13.4.513-522.2000

14. Deasy BM, Rea MC, Fitzgerald GF, Cogan TM, Beresford TP. A rapid PCR based method to distinguish between Lactococcus and Enterococcus. Syst Appl Microbiol. 2000;23:510-22. https://doi.org/10.1016/S0723-2020(00)80025-9

15. Dutka-Malen S, Evers S, Courvalin P. Detection of glycopeptide resistance genotypes and identification to the species level of clinically relevant enterococci by PCR. J Clin Microbiol. 1995;33:24-7.

16. Lane DJ. $16 \mathrm{~S} / 23 \mathrm{~S}$ rRNA sequencing. In: Stackebrandt E, Goodfellow M, editors. Nucleic acid techniques in bacterial systematics. Chichester, UK: John Wiley \& Sons; 1991. pp. 115-75.

17. Nübel U, Engelen B, Felske A, Snaidr J, Wieshuber A, Amann RI, et al. Sequence heterogeneities of genes encoding 16S rRNAs in Paenibacillus polymyxa detected by temperature gradient gel electrophoresis. J Bacteriol. 1996;178:5636-43. https://doi.org/10.1128/jb.178.19.5636-5643.1996

18. Huey B, Hall J. Hypervariable DNA fingerprinting in Escherichia coli: minisatellite probe from bacteriophage M13. J Bacteriol. 1989;171:2528-32.

https://doi.org/10.1128/jb.171.5.2528-2532.1989

19. Křížova J, Španová A, Rittich B. RAPD and rep-PCR fingerprinting for characterization of Bifidobacterium species. Folia Microbiol. 2008;53:99-104. https://doi.org/10.1007/s12223-008-0014-1

20. Akopyanz N, Bukanov NO, Westblom TU, Kresovich S, Berg DE. DNA diversity among clinical isolates of Helicobacter pylori detected by PCR-based RAPD fingerprinting. Nucleic Acids Res. 1992;20:5137-42. https://doi.org/10.1093/nar/20.19.5137

21. Warsa UC, Nonoyama M, Ida T, Okamoto R, Okubo T, Shimauchi $\mathrm{C}$, et al. Detection of tet(K) and tet(M) in Staphylococcus aureus of Asian countries by the polymerase chain reaction. J Antibiot. 1996;49:1127-32.

https://doi.org/10.7164/antibiotics.49.1127

22. Ng LK, Martin I, Alfa M, Mulvey M. Multiplex PCR for the detection of tetracycline resistant genes. Mol Cell Probe. 2001;4:209-15. https://doi.org/10.1006/mcpr.2001.0363

23. Sutcliffe J, Grebe T, Tait-Kamradt A, Wondrack L. Detection of erythromycin-resistant determinants by PCR. Antimicrob Agents Chemoter. 1996;40:2562-6.

24. Schreiner K, Hagn A, Kyselková M, Moënne-Loccoz Y, Welzl G, Munch JC, Schloter M. Comparison of barley succession and take-all disease as environmental factors shaping the rhizobacterial community during take-all decline. Appl Environ Microbiol. 2010;76:4703-12. https://doi.org/10.1128/AEM.00481-10

25. Mrkonjić Fuka M, Engel M, Haesler EF, Welzl G, Munch JC, Schloter M. Diversity of proteolytic community encoding for subtilisin in an arable field: spatial and temporal variability. Biol Fertil Soils. 2008;45:185-91. https://doi.org/10.1007/s00374-008-0319-x

26. BioNumerics v. 7.6. Gent, Belgium; Applied Maths NV; 2016. Available from: http://www.applied-maths.com.

27. Vauterin L, Vauterin P. Computer-aided objective comparison of electrophoretic patterns for grouping and identification of microorganisms. Eur Microbiol. 1992;1:37-41.

28. Jamaly N, Benjouad A, Comunian R, Daga E, Bouksaim M. Characterization of Enterococci isolated from Moroccan dairy products. Afr J Microbiol Res. 2010;4:1768-74. 
29. Savoy de Giori G, Hébert EM. Methods to determine proteolytic activity of lactic acid bacteria. In: Spencer JFT, de Ragout Spencer AL (editors). Food microbiology protocols. Methods in biotechnology vol. 14. Totowa, New Jersey, USA: Humana Press Inc; 2001. pp. 197-202. https://doi.org/10.1385/1-59259-029-2:197

30. Doleyres Y, Fliss I, Lacroix C. Increased stress tolerance of Bifidobacterium longum and Lactococcus lactis produced during continuous mixed-strain immobilized-cell fermentation. J Appl Microbiol. 2004;97:527-39. https://doi.org/10.1111/j.1365-2672.2004.02326.x

31. Nueno-Palop C, Narbad A. Probiotic assessment of Enterococcus faecalis CP58 isolated from human gut. Int J Food Microbiol. 2011;145:390-4. https://doi.org/10.1016/j.ijfoodmicro.2010.12.029

32. Fortina MG, Ricci G, Borgo F, Manachini PL, Arends K, Schiwon $\mathrm{K}$, et al. A survey on biotechnological potential and safety of the novel Enterococcus species of dairy origin, E. italicus. Int J Food Microbiol. 2008;123:204-11. https://doi.org/10.1016/j.ijfoodmicro.2008.01.014

33. Del Re B, Sgorbati B, Miglioli M, Palenzona D. Adhesion, autoaggregation and hydrophobicity of 13 strains of Bifidobacterium longum. Lett Appl Microbiol. 2000;31:438-42. https://doi.org/10.1046/j.1365-2672.2000.00845.x

34. M100-S15. Fifteenth informational supplement. Performance standards for antimicrobial susceptibility testing. Wayne, PA, USA: Clinical and Laboratory Standards Institute (CLSI); 2005.

35. Čanžek Majhenič A, Rogelj I, Perko B. Enterococci from Tolminc cheese: population structure, antibiotic susceptibility and incidence of virulence determinants. Int J Food Microbiol. 2005;102:239-44. https://doi.org/10.1016/j.ijfoodmicro.2004.12.021

36. The $\mathrm{R}$ project for statistical computing, $\mathrm{R}$ software v. 3.1.2, The $R$ foundation, Vienna, Austria; 2002. Available from: http://www.r-project.org.

37. International Commission on Microbiological Specifications for Foods (ICMSF). Microorganisms in foods 1: their significance and methods of enumeration represents a major step in establishing a common understanding of, and developing standard methods for, important foodborne microorganisms. Toronto, Canada: University of Toronto Press; 1978.

38. Teuber M, Perreten V, Wirsching F. Antibiotic-resistant bacteria: The new dimension in food microbiology. Lebensm Technol. 1996;29:182-199 (in German). https://doi.org/10.3929/ethz-a-004270972

39. Sarantinopoulos P, Andrighetto C, Georgalaki MD, Rea MC, Lombardi A, Cogan TM, et al. Biochemical properties of enterococci relevant to their technological performance. Int Dairy J. 2001;11:621-47. https://doi.org/10.1016/S0958-6946(01)00087-5

40. Özdemir GB, Oryaşın E, Bıyık HH, Özteber M, Bozdoğan B. Phenotypic and genotypic characterization of bacteriocins in enterococcal isolates of different sources. Indian J Microbiol. 2011;51:182-7. https://doi.org/10.1007/s12088-011-0143-0

41. Hosseini SV, Arlindo S, Böhme K, Fernández-No C, Calo-Mata P, Barros-Velázquez J. Molecular and probiotic characterization of bacteriocin producing Enterococcus faecium strains isolated from nonfermented animal foods. J Appl Microbiol. 2009;107:1392-403. https://doi.org/10.1111/j.1365-2672.2009.04327.x

42. Morandi S, Silvetti T, Brasca M. Biotechnological and safety characterization of Enterococcus lactis, a recently described species of dairy origin. Antonie Leeuwenhoek. 2013;103:239-49. https://doi.org/10.1007/s10482-012-9806-z

43. Olsen RH, Schønheyder HC, Christensen H, Bisgaard M. Enterococcus faecalis of human and poultry origin share virulence genes supporting the zoonotic potential of E. faecalis. Zoonoses Public Health. 2012;59:256-63. https://doi.org/10.1111/j.1863-2378.2011.01442.x

44. Yılmaz EŞ, Aslantaş Ö, Önen SP, Türkyılmaz S, Kürekci C. Prevalence, antimicrobial resistance and virulence traits in enterococci from food of animal origin in Turkey. LWT Food Sci Technol. 2016;66:20-6.

https://doi.org/10.1016/j.lwt.2015.10.009

45. Semedo T, Santos MA, Lopes MFS, Figueiredo Marques JJ, Barreto Crespo MT, Tenreiro R. Virulence factors in food, clinical and reference enterococci: a common trait in the genus? Syst Appl Microbiol. 2003;26:13-22.

https://doi.org/10.1078/072320203322337263

46. Jahan M, Holley RA. Incidence of virulence factors in enterococci from raw and fermented meat and biofilm forming capacity at $25^{\circ} \mathrm{C}$ and $37^{\circ} \mathrm{C}$. Int J Food Microbiol. 2014;170: 65-9.

https://doi.org/10.1016/j.ijfoodmicro.2013.11.002

47. Barbosa J, Gibbs PA, Teixeira P. Virulence factors among enterococci isolated from traditional fermented meat products produced in the north of Portugal. Food Control. 2010;21: 651-6.

https://doi.org/10.1016/j.foodcont.2009.10.002

48. Aberna RA, Prabakaran K. Evaluation for the association of virulence determinants among E. faecalis with its clinical outcome. Int J Biol Med Res. 2011;2: 523-7.

49. Domann E, Hain T, Ghai R, Billion A, Kuenne C, Zimmermann K, Chakraborty T. Comparative genomic analysis for the presence of potential enterococcal virulence factors in the probiotic Enterococcus faecalis strain Symbioflor 1. Int J Med Microbiol. 2007;297:533-9.

https://doi.org/10.1016/j.ijmm.2007.02.008

50. Heaton MP, Handwerger S. Conjugative mobilization of a vancomycin resistance plasmid by a putative Enterococcus faecium sex pheromone response plasmid. Microb Drug Resist. 1995;1:177-83.

https://doi.org/10.1089/mdr.1995.1.177

51. Huycke MM, Sahm DF, Gilmore MS. Multiple-drug resistant enterococci: the nature of the problem and an agenda for the future. Emerg Infect Dis. 1998;4:239. https://doi.org/10.3201/eid0402.980211

52. Aslam M, Diarra MS, Checkley S, Bohaychuk V, Masson L. Characterization of antimicrobial resistance and virulence genes in Enterococcus spp. isolated from retail meats in Alberta, Canada. Int J Food Microbiol. 2012;156:222-30. https://doi.org/10.1016/j.ijfoodmicro.2012.03.026

53. Klibi N, Said LB, Jouini A, Slama KB, López M, Sallem RB, et al. Species distribution, antibiotic resistance and virulence traits in enterococci from meat in Tunisia. Meat Sci. 2013;93: 675-80. https://doi.org/10.1016/j.meatsci.2012.11.020

54. Özmen Toğay S, Çelebi Keskin A, Açık L, Temiz A. Virulence genes, antibiotic resistance and plasmid profiles of Enterococcus faecalis and Enterococcus faecium from naturally fermented Turkish foods. J Appl Microbiol. 2010;109:1084-92. https://doi.org/10.1111/j.1365-2672.2010.04763.x

55. Agersø Y, Pedersen AG, Aarestrup FM. Identification of Tn5397-like and Tn916-like transposons and diversity of the tetracycline resistance gene tet(M) in enterococci from humans, pigs and poultry. J Antimicrob Chemother. 2006;57: 832-9. https://doi.org/10.1093/jac/dk1069 